\title{
What makes a non-Muslim purchase halal food in a Muslim country? An application of theory of planned behaviour
}

\author{
Dayang Haryani Diana Ag. Damit ${ }^{a}$, Amran Harun ${ }^{\text {, }}$, David Martin ${ }^{\mathrm{b}}$, Baban Jabbar Othman ${ }^{\mathrm{c}}$, \\ Bestoon Othman ${ }^{\text {and Halim Ahmad }}{ }^{\mathrm{a}}$
}

${ }^{a}$ Faculty of Business and Management, Universiti Teknologi MARA, Sabah Kota Kinabalu Campus, 88997, Kota Kinabalu, Sabah, Malaysia

${ }^{b}$ Faculty Technology Management and Business, Universiti Tun Hussien Onn Malaysia 86400 Parit Raja, Johor, Malaysia

'Department of Business Administration, College of Administration \& Financial sciences. Knowledge University, Malaysia

${ }^{d}$ Department of Business Administration, Koya Technical Institute, Erbil Polytechnic University and Universiti Tun Hussein Onn, Malaysia

\section{H R O N I C L E}

\section{Article history:}

Received: June 6, 2019

Received in revised format: June 292019

Accepted: July 2, 2019

Available online:

July 2, 2019

Keywords:

Non-Muslim consumer

Attitude, subjective norm

Perceived behavioural control

Repurchase intention, halal food

\section{A B S T R A C T}

Theory of Planned Behaviour (TPB) has become a prominent theory in describing the relationship between attitude and behaviour. TPB utilizes attitudes, subjective norms and perceived behavioural control to predict -intentionll. Studies of similar topics concentrating on non-Muslim consumers as respondents particularly exploring in their repurchase intention on Halal food are uncommon. Therefore, this study attempts to demonstrate the TPB in exploring the non-Muslim consumer repurchase intention of halal food products. Data were collected through a self-administered questionnaire survey of 415 non-Muslim consumers in Malaysia. The result of Structural Equation Analyses indicate that non-Muslim consumers' attitude, subjective norm, and perceived behavioural control toward halal food product positively influenced their intention to repurchase halal food. The conclusions and several recommendations for future research consideration are presented in the final section.

\section{Introduction}

Halal is typically known to have a close relationship with the Muslims society in which it governs every aspect of their lives - from proper conduct to food consumption (Rezai et al., 2015). In the context of the Muslim dietary law, halal food refers to a particular food that is permissible under the code of Islamic law. Bonne et al. (2007) noted that the concept of halal in food conveys the idea of hygienic and wholesomeness food for the consumers' safe consumption. The credence of the product essentially confirmed the product's halal status, and the worldwide market acknowledged that a certified halal food product has an undisputable quality assurance (Mohayidin \& Kamarulzaman, 2014). Thus, the product's excellent attributes reflected by the halal status have made it very appealing to the consumer.

\footnotetext{
* Corresponding author. Tel.: +60146856048

E-mail address: dayan457@sabah.uitm.edu.my (D. H. Diana Ag. Damit) 
In terms of the business perspective, the halal market has become a lucrative trade attracting many of the industrial players. Furthermore, a vast number of non-Muslim consumers are inclined to buy halal products because of their conviction that halal certified products are hygienic and safe to consume (Yusoff et al., 2015). Nowadays, the halal food product is not strictly sought by Muslim consumer only. It has also become a preference among non-Muslim consumer, which suggests that the halal concept and halal products have become a globally accepted concept and generally relevant to every person (Hussain et al., 2016). Thus, it is a reasonable notion that halal products are pertinent to and viable for non-Muslims consumers as well. Past researchers suggest that the future studies should emphasise on non-Muslim consumers' engagement with halal product (Mathew et al., 2014; Ismail \& Nasiruddin, 2014; Yuhanis \& Chok, 2013). Additionally, Ismail and Nasiruddin (2014) propose further investigation of the consumption pattern of non-Muslim consumers and the influential factors of their purchasing behaviour toward the halal product. However, research on the decisive factors that affect the non-Muslim consumers' repurchase intention toward Halal product is scant. The lack of such work has instigated this study, which aims to explore and comprehend the relationship among attitude, subjective norm, perceived behavioural control, and repurchase intention of non-Muslim Malaysian consumers toward halal food.

\section{Literature review}

\subsection{Theoretical Consideration}

Theory of Planned Behaviour (TPB) (Ajzen, 1991) was adapted to provide the foundation of the construct of this study. TPB stipulates that a consumer's intention to purchase any product could be predicted through the three main factors namely, attitude, subject norms, and perceived behavioural control. The prominent theory of planned behaviour holds the assumption that a person's intention can be drawn from the combination of attitude, subjective norm, and perceived behaviour control. Despite being developed some decades ago, TBP continues to be useful and relevant in providing the insight of human behaviour, specifically in the halal studies (Ahasanul et al., 2015; Syed Shah \& Nazura, 2011; Norazah $\&$ Abang Sulaiman, 2016). Therefore, this study has developed a conceptual framework to appraise the three determinants identified in TPB in relation to the repurchase intention towards halal food product, which is illustrated in Fig. 1

\subsection{Attitude towards halal food}

Attitude is imperative in the field of marketing. Therefore, understanding the consumers' attitude is crucial as attitude affects their behavioural intentions (Kraft \& Kraft, 2005). Individual experience and group interaction could lead to resisting attitude change (Asiegbu et al., 2012). On the other hand, attitude could serve as guidance for people to behave consistently toward a similar object (Asiegbu et al., 2012). Attitude has been widely examined as a variable in the extant literature on sustainable consumption behaviour because attitude could indicate a person's favourable or unfavourable general feelings toward a particular issue (Kendrick \& Olson, 2012). The consumers' strong attitude toward a product is a good predictor of which products the consumers would tend to purchase (Engel et al., 1995). Theoretically, the consumers' positive or favourable attitudes would cause them to engage in a behaviour that leads to positive outcomes (Haque et al., 2015). Accordingly, numerous past researchers acknowledged the importance to investigate and understand consumers' attitude toward a halal product (Haque et al., 2015). A study by Shah Alam and Mohamed Sayuti (2011) suggests that attitude played a substantive role in influencing Malaysian consumers' intention to purchase halal food products because consumers with a high positive attitude are more likely to purchase halal food products. Despite this notion, the investigation on the consumers' attitude and purchase intention are expected to be slightly different (Said et al., 2014) since the classification of halal food products and non-halal products differ. Following this argument, the present study proposes that non-Muslim consumers' attitude toward halal food is the driving force in their intention of repurchasing halal foods; hence, the following hypothesis is developed: 
Hypothesis 1: The attitude of non-Muslim consumers towards halal food will positively influence their repurchase intention of halal food

\subsection{Subjective norm}

According to Ajzen (1991), subjective norm is perceived as social pressure to engage or not in a specific behaviour. Social norm, on the other hand, represents an individual's perception or opinion of what others believed the individual should do (Finlay et al., 1999). It suggests whether the individuals should perform or not a particular behaviour in a specific situation; in other words, it refers to the mental representation of others in a person's relationship or vice versa. Social norms perceived the importance or relevance of relatives, friends, or colleagues and the extent to which their approval will shape the intentions and describe a consumer's referent of others' (e.g., family and friends) view on his or her behaviour and how this view motivates the consumer to comply with the others' belief. One of the important determinants of consumer behaviour is the impact of people around the individual (Ergen, 2016). TPB describes that subjective norm is set as the second determinant factor, which triggers human behavioural intention (Hasbullah et al., 2015). This discussion leads to the second hypothesis of this study that subjective norm positively influences the non-Muslim Malaysian consumers' repurchase intention of halal food; hence, the next proposed hypothesis is as follows:

Hypothesis 2: Subjective norm positively influences the non-Muslim consumers' repurchase intention of halal foods.

\subsection{Perceived behavioural control}

The individual's beliefs determine perceived behavioural control about the power of both situational and internal factors in facilitating the performance of behaviour (Ajzen, 1991). In other words, perceived behavioural control steers the individual's perception of how to conduct an intended behaviour. Looking into the halal food purchasing scenario, Shah Alam and Mohamed Sayuti (2011) found that perceived behavioural control is not a critical predictor to the behavioural intention of buying halal food in Malaysia. Contrarily, Golnaz et al. (2010) who noted the non-Muslims' awareness of halal principles suggested that perceived behavioural control (e.g., food safety, environmentally friendly, and fair trade) influence the behavioural intention of purchasing halal food products. Companies have to adhere to stringent rules for processing halal foods compared with non-halal food; thus, this has enhanced the consumers' confidence towards halal food (Cutler, 2007). A product's halal status is not just an assurance that the product is permissible for the Muslims consumption, but it has also become a global symbol of quality and lifestyle choice (Elasrag, 2016). Consequently, consumers of halal products will likely demonstrate a higher purchase intention and engage in the actual behaviour as they feel a sense of control in their decisions to buy a halal product that is supported by its credence. Therefore, it is hypothesised that behavioural control could positively influence non-Muslim Malaysian consumers' repurchase intention of halal food. Hence, the following hypothesis:

Hypothesis 3: Perceived behavioural control will positively influence non-Muslim consumers' repurchase intention of halal food.

\subsection{Repurchase intention of halal food}

The present study also aims to understand the repurchase intention of halal food among non-Muslim consumers. In relation to $\mathrm{TPB}$, several researchers focused on investigating the context of repurchase intention of the consumers. From the consumer behavioural perspective, purchase intention is found to be strongly associated with repurchase intention. Therefore, observing the customers' repurchase intention is more important compared with purchase intention as repurchase intention shows the customer's willingness to purchase the same product in the future. Likewise, Ibzan et al. (2016) conclude a positive 
relationship between consumer satisfactions and repurchase intention. In addition, the authors postulated that satisfied consumers are more likely to continue their relationship with a particular firm than dissatisfied consumers. Therefore, the findings highlighted the importance of a company in putting extra consideration on the issue of repurchase intention to cope with the stiff market competition (Roos \& Gustafsson, 2007). The reason for this is because consumers would repurchase the same product from the same company or brand if they deemed that they are receiving a greater value the company than that offered by other companies (Wu et al., 2014). While most of the previous studies focused on the purchase intention consequence as a behaviour in the halal context (Yuhanis \& Nyen, 2013; Ahmad et al., 2013; Syed Shah \& Nazura, 2011), studies that examined the role of attitude, subjective norm, and perceived behavioural control in influencing the repurchase intention of halal product among non-Moslem consumers are scarce. Consequently, it highlights the gap that this study aims to examine, specifically the repurchase intention of non-Muslim consumer towards halal food.

\section{Conceptual research model}

This study establishes its framework based on TPB as depicted in Fig. 1. The independent variables of this study are attitude, subjective norm, and perceived behaviour control, while the dependent variable is the repurchase intention towards halal food. Accordingly, the role of attitude toward halal foods is postulated to have a direct relationship with the non-Muslim consumers' repurchase intention towards halal food. In addition, this study also aims to explore the direct relationship between the role of subjective norms and perceived behavioural control and repurchase intention. Fig. 1 illustrates the conceptual model constructed for the purpose of this study.

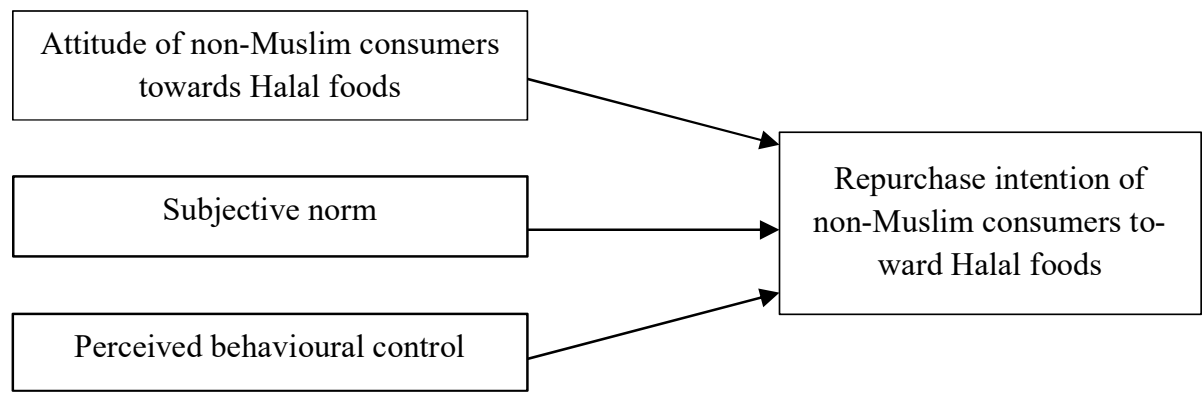

Fig. 1. A schematic diagram of the conceptual framework

\section{Methodology}

\subsection{Data Collection and Survey Instrument}

The study applied the descriptive research method using cross-sectional data collection. Survey method is used to collect primary data from the respondents. Questionnaires were structured based on the observed variables of this study. The target population for this research is non-Muslims consumers in five selected states in Malaysia representing specific regions, namely Sabah, Selangor, Johor, Penang, and Pahang. The target respondents were selected based on their prior experience of purchasing and consuming halal food product. The questionnaire is designed to analyse the attitude and subjective norm towards halal food. All of the items that measured the proposed constructs were adopted and modified from the past scholars' works. Sample questionnaires about halal food and the related constructs used were adopted and adapted from the work of Yuhanis and Nyen (2013), Khalek and Ismail (2015), Abd Rahman et al. (2015), and Haque et al. (2015). The questionnaires were divided into several sections (A, $\mathrm{C}$, and $\mathrm{B}$ ). The first section consists of questions related to the non-Muslims consumers' behavioural characteristics towards halal food product, particularly their shopping habits involving halal food (e.g., buying behaviour and the frequency of purchasing). The second section of the questionnaire aims to 
capture the response of non-Muslim consumers concerning different constructs of the study based on the existing literature as mentioned earlier. In this section, the questionnaire that assessed the proposed variables were rated with a 5-point Likert-scale to illustrate the respondent's degree of agreement; where a scale point " 5 " indicated Strongly Agree; point "4" indicated Agree; point "3" indicated Slightly Agree; point "4" indicated Neither Disagree nor Agree; point "3" indicated neither agree nor disagree; point "2" indicated Disagree; and lastly, point "1" indicated Strongly Disagree. The last section of the questionnaire contained questions on socio-demographic characteristics of the respondents (e.g., gender, age, ethnicity, religion).

To test the appropriateness of the chosen items for the study attributes and the clarity of the questions, the questionnaire was pre-tested on a small sample of individuals ( 20 people). The final version of the questionnaire was administrated by trained interviewers who randomly and conveniently intercepted the targeted respondents at several hypermarkets and supermarkets. These supermarkets and hypermarkets are located in the selected regions in Malaysia, namely Selangor, Penang, Johor, Pahang, and Sabah. Data were collected from non-Muslim consumers from different states of Malaysia. The respondents of this study were selected randomly to avoid researcher's bias. They were approached and asked a screening question whether they have prior experience in buying a halal food product, and each participants' age was verified to be at least 18 years old. Upon confirmation on the screening questions, the selected respondents were then handed the questionnaire to be filled in anonymously by the interviewer. As a result, a total of 415 set of questionnaires were gathered for further analysis. Statistics description of the respondents' socio-demographic characteristics and the result of the analysis are discussed in the following section.

\section{Data analysis and results}

The collected data were analysed using two different steps. First, the data were keyed-in into the Statistical Package for Social Science (SPSS), and descriptive analysis was performed to describe the sociodemographic characteristics of the sample. Second, Partial Least Square Equation Modelling (PLSSEM) was employed through SmartPLS 3.0 to examine the construct of the model.

\subsection{Descriptive Analysis}

Descriptive analysis is employed to provide information about the respondents' socio-demographic characteristics. For the present study, $51.8 \%$ of the respondents were female and $48.2 \%$ were male. The age range of $18-25$ years represented $48.6 \%$ of the respondents, followed by $26-33$ years $(23.9 \%), 34-41$ years $(15.1 \%), 42-49$ years $(8.1 \%), 50-57$ years $(3.6 \%)$, and $58-65$ years $(0.7 \%)$. Meanwhile, the Chinese $(38.5 \%)$ made up the majority of the respondents, followed by the Bumiputeras $(30.4 \%)$, Indians $(23.9 \%)$ and others (7.2\%). The respondents were segregated into eight categories of religion. The majority of the respondents practice Christianity (48.0\%); Buddhism came in second (26.4\%), followed by Hinduism (19.1\%). A small percentage of the respondents was practising other religions.

\subsection{Assessment of Measurement Model}

Table 1 presents the assessment of the construct reliability and convergent reliability of this study. As illustrated, the composite reliability for attitude construct is 0.916 , subjective norm construct is 0.918 , while repurchase intention construct values of CR is 0.940 . All the above mentioned CR values indicate that the constructs did have internal consistency. Basically, Cronbach's alpha and Composite reliability are interpreted similarly (Hair et al., 2017; Henseler et al., 2009). Prior research suggests that the threshold level of 0.60 or higher is required to demonstrate satisfactory composite reliability in exploratory research, but not exceeding the 0.95 level (Hair et al., 2017). 
The next measurement testing is by observing the indicators' reliability where the test is to assess the extent to which a variable or a set of variables is consistent with what it intends to measure (Urbach \& Ahlemann, 2010). Hair et al. (2017) suggested that the indicator loadings should be greater than 0.7. Correspondingly, it can be seen in Table 1 that the indicator reliability values range from 0.755 to 0.910 , which exceeded the threshold value of 0.7 . The results obtained from this step offers a significant hint that these constructs demonstrate an adequate convergent validity resulting in no removal of items on the basis of low loadings. Additionally, the assessment of the measurement model also reveals that all the construct AVE values are above 0.7. The result indicates that the AVE of the study achieved the minimum value 0.5 of the average variance extracted (AVE) implying that the items loaded to the respective constructs explain more than $50 \%$ of the constructs' variance (Hair et al., 2014).

Table 1

Internal Consistency and Convergent Validity

\begin{tabular}{|c|c|c|c|c|}
\hline Constructs & Research items & Loadings & $\begin{array}{l}\text { Composite } \\
\text { Reliability }\end{array}$ & AVE \\
\hline \multirow[t]{4}{*}{ Attitude } & I feel comfortable to consume Halal food products & 0.877 & \multirow{4}{*}{0.920} & \multirow{4}{*}{0.743} \\
\hline & I sometime prefer to purchase Halal food products & 0.840 & & \\
\hline & I like to choose food products that is Halal & 0.878 & & \\
\hline & My family members are also buying Halal food product & 0.851 & & \\
\hline \multirow{3}{*}{$\begin{array}{c}\text { Perceived } \\
\text { behavioral } \\
\text { control }\end{array}$} & I consumed Halal product because it is environmentally friendly & 0.867 & \multirow{3}{*}{0.914} & \multirow{3}{*}{0.779} \\
\hline & $\begin{array}{l}\text { Consuming safe product for example Halal food product is important } \\
\text { for me }\end{array}$ & 0.871 & & \\
\hline & Consuming Halal food product represent a natural way of living & 0.910 & & \\
\hline \multirow{5}{*}{$\begin{array}{l}\text { Repurchase } \\
\text { intention }\end{array}$} & Most probably I'll continue to choose Halal food products & 0.873 & \multirow{5}{*}{0.941} & \multirow{5}{*}{0.762} \\
\hline & I intend to repurchase Halal food product in the future & 0.879 & & \\
\hline & $\begin{array}{l}\text { The probability that I would consider buying Halal food product is } \\
\text { high }\end{array}$ & 0.870 & & \\
\hline & I am most probably will repurchase Halal food product in the future & 0.881 & & \\
\hline & Choosing food product that is Halal is a good idea & 0.862 & & \\
\hline \multirow[t]{5}{*}{ Subjective norm } & I buy Halal food product to please my Muslim friends & 0.808 & \multirow{5}{*}{0.927} & \multirow{5}{*}{0.718} \\
\hline & $\begin{array}{l}\text { My Muslim friends sometime influence me to consume Halal food } \\
\text { product }\end{array}$ & 0.884 & & \\
\hline & $\begin{array}{l}\text { My Muslim friends who are close to me think that I should choose } \\
\text { Halal food }\end{array}$ & 0.910 & & \\
\hline & My Muslims friends encourage me to choose Halal food product & 0.907 & & \\
\hline & My family members are also buying Halal food product & 0.755 & & \\
\hline
\end{tabular}

In addition to the assessment of the measurement model, Fornell and Larcker (1981) and Henseler's heterotrait-monotrait (HTMT) (2015) were performed to assess the discriminant validity. Table 2 illustrates Fornell and Larcker Criterion. The results obtained from this analysis reveal that the square root of AVE for each construct is larger than the correlation estimate of the construct. Therefore, it is noted that the constructs are contrasting from one another following Fornell and Larcker's (1981) discriminant validity criterion.

Table 2

Fornell and Larcker Criterion

\begin{tabular}{lcccc}
\hline \multicolumn{1}{c}{ Constructs } & Attitude & $\begin{array}{c}\text { Perceived behav- } \\
\text { ioral control }\end{array}$ & Repurchase intention & Subjective norm \\
\hline Attitude & 0.862 & & & \\
Perceived behavioral control & 0.587 & 0.883 & & \\
Repurchase intention & 0.743 & 0.523 & 0.873 & 0.847 \\
Subjective norm & 0.603 & 0.466 & 0.525 & \\
\hline
\end{tabular}

Note: Diagonal elements highlighted in bold represent the square root of AVE

To further assess the discriminant validity, rigorous assessments of Heterotrait-Monotrait Ratio (HTMT) (Henseler et al., 2015) were employed, and theresult is shown in Table 3. This result demonstrates that the values are lower than the required threshold value HTMT0.90, indicating that all constructs are distinctively different, and the descriptive validity of this study is established. 
Table 3

Heterotrait-Monotrait Ratio (HTMT)

\begin{tabular}{lcccc}
\multicolumn{1}{c}{ Constructs } & Attitude & $\begin{array}{c}\text { Perceived } \\
\text { behavioural } \\
\text { control }\end{array}$ & Repurchase intention Subjective norm \\
\hline Attitude & & & & \\
Perceived behavioural control & 0.673 & & & \\
Repurchase intention & 0.822 & 0.587 & 0.561 & \\
Subjective norm & 0.657 & 0.518 & \\
\hline
\end{tabular}

Attitude

Perceived behavioural control $\quad 0.673$

Criteria: Discriminant validity is established at HTMT0.90

\subsection{Assessment of Structural Model}

Table 4 shows all the outline relationships for the proposed model are significant 0.000 , indicating the result that can be considered statistically significant at $p$-value 0.05 . The results were obtained through path coefficient assessment using the bootstrapping procedure for the hypothesised relationships. It was found that all direct relationship were significant (Attitude Repurchase intention, $\beta=0.615, t=11.421$, $\mathrm{p}=0.05$; Subjective norm Repurchase intention, $\beta=0.101, \mathrm{t}=2.077, \mathrm{p}=0.05$; Perceived behavioural control Repurchase intention, $\beta=0.114, \mathrm{t}=2.054, \mathrm{p}=0.05$ ). Thus, the above structural model assessment leads us to confirm that the three different independent variables; namely attitude toward halal food, subjective norm and perceived behavioural control positively and significantly influenced non-Muslim consumers' repurchase intention towards halal food products. The result evidenced that the identified factors have a significant impact on the non-Muslim consumers' intention to repurchase halal food product.

Table 4

Summary of bootstrapping result

\begin{tabular}{lcccrr}
\multicolumn{1}{c}{ Relationship } & $\begin{array}{c}\text { Direct Effect } \\
(\beta)\end{array}$ & Standard Error & T Statistics & P Values & Decision \\
\hline Attitude $\rightarrow$ Repurchase intention & 0.615 & 0.054 & 11.421 & 0.000 & Supported \\
Subjective norm $\rightarrow$ repurchase intention & 0.101 & 0.049 & 2.077 & 0.019 & Supported \\
Perceived behavioral control $\rightarrow$ Repurchase intention & 0.114 & 0.056 & 2.054 & 0.020 & Supported \\
\hline${ }_{*}^{*}<0.05$ (one-tailed) & & & & &
\end{tabular}

$* \mathrm{p}<0.05$ (one-tailed)

Additionally, the assessment of coefficient of determination $\left(\mathrm{R}^{2}\right)$ for repurchase intention is 0.570 , which suggests that attitude, subjective norm, and perceived behavioural control explained $57 \%$ of the repurchase intention of non-Muslim consumers toward halal food.

\section{Discussion and conclusion}

The purpose of this study is to identify the effect of non-Muslim consumers' attitude toward halal food, and the role of subjective norm in their repurchase intention of halal food. Respondents targeted for the study are non-Muslims consumer in Malaysia. TPB is used as the foundation for understanding the relationship between the constructs in which a structural model was developed by constructing the attitude and subjective norm to predict repurchase intention. Data obtained from the distributed questionnaire survey non-Muslim consumers in Malaysia were analysed using SmartPLS 3.0. The results of this study provide insightful and interesting findings that highlighted the importance of halal food concept in predicting consumer repurchases intention. The validation of the hypotheses of this study support the three notions: (1) non-Muslim consumers' attitude toward halal food has a positive influence on their repurchase intention of halal food; (2) subjective norm has a positive influence on non-Muslim consumers' repurchase intention on halal food; and (3) perceived behavioural control has a positive influence on non-Muslim consumers' repurchase intention of on halal food. Additionally, the findings reveal that non-Muslim consumers engaged with a positive attitude toward halal food, which is sufficient to predict their intention to repurchase halal food in the future. In fact, of all the independent variables included in 
this study, the attitude was found to be the most substantive predictor that influenced the Malaysian nonMuslim consumers' repurchase intention of halal food. The findings also corroborate the study by Shah Alam and Mohamed Sayuti (2011) who suggested that attitude played a more significant role in influencing the Malaysian purchase intention of halal food.

Furthermore, grounded on TBP, it was proven that individuals' attitude strongly shaped their behavioural intention on a subject matter (Ajzen, 1991). The findings of this study also support the existing literature, which states that the more positive an attitude toward the halal product, the higher the likelihood to purchase it. In a nutshell, it can be construed that consumers' who have a strong favourable feeling toward halal food may likely have a strong repurchase intention of the halal product. Therefore, the empirical result of this study also shows that non-Muslim consumer placed greater importance on subjective norm in forming their intentional behaviour to repurchase halal food. It suggests that when making decisions to repurchase halal food product, non-Muslim consumers are more likely to be inspired by others such as friends, family members, or the public. Besides, it was noted that having Muslim friends could also trigger a strong intention to repurchase halal food. Moreover, the study's findings supported a study by Ajzen (1991) who suggests that social pressure would determine the individuals' decision to perform or not to perform a certain behaviour. The significant role of subjective norm in forming the repurchase intention of non-Muslim consumers toward halal food might reflect the Malaysian characteristic of collectivism principle subscribed by the society. This principle emphasised the importance of a group to which the individuals belong. Coincidently, this finding is also in a similar vein with the notion posited by Norazah and Abang Sulaiman (2016) that the role of subjective norm could positively have an impact on the consumers' behavioural intention to patronise halal stores.

Closer scrutiny discovers that Hypothesis 3 tested the association between perceived behavioural control and non-Muslim consumers' repurchase intention toward halal food product. The findings reveal that perceived behavioural control could positively influence non-Muslim consumers' intention to repurchase halal food. Although the role of perceived behavioural control is not a critical predictor of repurchase intention behaviour, it is sufficient enough to state that perceived behavioural control could be a significant predictor of non-Muslim consumers' intention to repurchase halal food product in the future. Prior research noted that perceived behavioural control has an impact on the consumers' intention to purchase halal food (Shah Alam \& Mohamed Sayuti 2011; Bonne et al., 2007). Correspondingly, the effect of perceived behavioural control of this study reflects the consumers' capacity to control their behaviour, and the confidence whether or not to perform a given behaviour, such as the concern over food safety, environmentally friendly food, and how consuming halal food product portrays the natural way of life (Haque et al., 2015). In summary, drawing from the argument on the application of Theory of Planned Behaviour (Ajzen, 1991) on the past research works, this present study has make a proposition on using theory planned behaviour as a basis in explaining the role of $i$ ) the role of attitude of nonMuslim consumers toward on Halal product to the repurchase intention of the non-Muslim consumers on Halal food product; ii) the role of subjective norm to the repurchase intention of the non-Muslim consumers on Halal product and iii) the influence of Perceived behavioural control repurchase intention of the non-Muslim consumers on Halal product.

\section{Implication and recommendation}

The major contribution of the study's findings is the solid argument it presents for halal food producers to consider extending their target market to include non-Muslim consumers. The study empirically shows that non-Muslim consumers nowadays have a favourable attitude toward halal food. Notably, the result also depicts that halal food is no longer strictly tied to the concept of religiously permissible food; halal food seems appealing to the eyes of consumer regardless of their religious background. Much effort is needed to capitalise available resources and to focus more on the marketing strategies to promote halal product and services as well as to ensure their attractiveness for both the consumers and industry players. 
Additionally, the findings of this study reinforce the need for managers to understand consumer attitude, social influence, and perceived behavioural control in relation to the consumer repurchase intention. These factors are found to have a significant influence on the consumers' repurchase intention of halal food. Moreover, halal businesses should not disregard the role of family and friends as they could influence an individual behavioural intention toward any subject. The strong multicultural practice saw Malaysian consumers are more receptive of and responsive to the diversity of food product available in the market. Marketing strategies should be designed to encourage repetitive purchase. One potential marketing strategy is to pursue the concept of safe and environmentally friendly halal products.

From the academic perspective, the study's finding indicates that the TPB model could effectively predict repurchase intention of halal food among non-Muslim consumers in Malaysia. While most of the previous studies empirically tested the robustness of the TPB theory in predicting purchase intentionbehaviour, there has been no study conducted in predicting the repurchasing behaviour of Malaysian non-Muslim toward halal food. Thus, this study conveniently addressed the research gap. In addition, the study also provides an excellent point of halal concept in consumerism issue for scholars' attention as it could serve as an extension of knowledge of the issue. Scholars of this field should seriously explore the repurchase intention topic as it could assist in the expectation and prediction of the consumers' final conduct in the halal context. Another substantial contribution of this study is the development of a clearly defined and structured theoretical model by combining different verified variables from the literature. In a nutshell, it represents an advancement of the antecedents of repurchase intention, which promotes greater understanding of consumer behavioural characteristics regarding halal products.

\section{References}

Abd Rahman, A., Asrarhaghighi, E., \& Ab Rahman, S. (2015). Consumers and Halal cosmetic products: knowledge, religiosity, attitude and intention. Journal of Islamic Marketing, 6(1), 148-163.

Ahmad, M., Kadir, S. A., \& Salehuddin, N. A. (2013). Perceptions and behavior's of Muslims and NonMuslims towards halal products. Journal of Social and Development Sciences, 4(6), 249.

Ajzen, I. (1991). The theory of Planned Behavior. Organizational Behavior and Human Decision Processes, 50(2), 179-211.

Asiegbu, I. F., Powei, D. M., \& Iruka, C. H. (2012). Consumer attitude: some reflections on its concept, trilogy, relationship with consumer behavior, and marketing implications. European Journal of Business and Management, 4(13), 38-50.

Bonne, K., Vermeir, I., Bergeaud-Blackler, F., \& Verbeke, W. (2007). Determinants of halal meat consumption in France. British Food Journal, 109(5), 367-386.

Cutler, T. R. (2007). Food safety drives growth in kosher \& halal foods. International Food Safety and Quality Network, available at: http://www. trcutlerinc. com/IFSQN, 205(201), 2007.

Elasrag, H. (2016). Halal industry: Key challenges and opportunities. Available at SSRN 2735417.

Ergen, A. (2016). The Impact of Attitude, Consumer Innovativeness and Interpersonal Influence on Functional Food Consumption. International Business Research, 9(4), 79.

Finlay, K. A., Trafimow, D., and Moroi, E. (1999).The Importance of Subjective Norms on Intentions to Perform Health Behaviors. Journal of Applied Social Psychology, 29(11), 2381-2393.

Fornell, C., \& Larcker, D.F. (1981). Evaluating Structural Equation Models with Unobservable and Measurement Error. Journal of Marketing Research, 34(2), 161-188.

Golnaz, R., Zainalabidin, M., Mad Nasir, S., \& Eddie Chiew, F. C. (2010). Non-Muslims' awareness of Halal principles and related food products in Malaysia. International Food Research Journal, 17(3), 667-674.

Haque, A., Sarwar, A., Yasmin, F., Tarofder, A. K., \& Hossain, M. A. (2015). Non-Muslim consumers' perception toward purchasing halal food products in Malaysia. Journal of Islamic Marketing, 6(1), 133-147. 
Khalek, A. A., \& Ismail, S. H. S. (2015). Why are we eating halal-using the theory of planned behavior in predicting halal food consumption among generation Y in Malaysia. International Journal of Social Science and Humanity, 5(7), 608-612.

Kraft, C. H., \& Kraft, M. G. (2005). Christianity in Culture: a study in dynamic biblical theologizing in cross cultural perspective. Orbis Books.

Hair Jr, J., Sarstedt, M., Hopkins, L., \& G. Kuppelwieser, V. (2014). Partial least squares structural equation modeling (PLS-SEM) An emerging tool in business research. European Business Review, 26(2), 106-121.

Hasbullah, N. A., Khairi, K. F., \& Aziz, M. R. A. (2015). The Theory of Planned Behaviour and The Impact of Moral Norm. Studies in Social Sciences and Humanities, 3(2), 61-70.

Henseler, J., Ringle, C.M. \& Sarteadt, M. (2015). A new criterion for assessing discriminant validity in variance-based structural equation modelling. Journal of the Academy of Marketing Science, 43(1), $115-135$.

Hussain, I., Rahman, S. U., Zaheer, A., \& Saleem, S. (2016). Integrating factors influencing consumers' halal products purchase: Application of theory of reasoned action. Journal of International Food \& Agribusiness Marketing, 28(1), 35-58.

Ibzan, E., Balarabe, F., \& Jakada, B. (2016). Consumer satisfaction and repurchase intentions. Developing Country Studies, 6(2), 96-100.

Kendrick, R. V., \& Olson, M. A. (2012). When feeling right leads to being right in the reporting of implicitly-formed attitudes, or how I learned to stop worrying and trust my gut. Journal of Experimental Social Psychology, 48(6), 1316-1321.

Mathew, V. N. (2014). Acceptance on halal food among non-Muslim consumers. Procedia-Social and Behavioral Sciences, 121, 262-271.

Mohayidin, M. G., \& Kamarulzaman, N. H. (2014). Consumers' preferences toward attributes of manufactured halal food products. Journal of International Food \& Agribusiness Marketing, 26(2), 125139.

Norazah, M. S., \& Abang Sulaiman, A. S. (2016). Does Halal image strengthen consumer intention to patronize Halal stores? Some insights from Malaysia. Journal of Islamic Marketing, 7(1), 120-132.

Rezai, G., Mohamed, Z., \& Shamsudin, M. N. (2015). Can halal be sustainable? Study on Malaysian consumers' perspective. Journal of Food Products Marketing, 21(6), 654-666.

Roos, I., \& Gustafsson, A. (2007). Understanding frequent switching patterns. Journal of Service Research, 10(1), 93-108.

Said, M., Hassan, F., \& Musa, R. (2011, December). Empirical study on the influence of country-oforigin on consumers' perception towards their purchase intention of Malaysia's Halal food products. In 2011 IEEE Colloquium on Humanities, Science and Engineering (pp. 865-870). IEEE.

Shah Alam, S., \& Mohamed Sayuti, N. (2011). Applying the Theory of Planned Behavior (TPB) in halal food purchasing. International Journal of Commerce and Management, 21(1), 8-20.

Urbach, N., \& Ahlemann, F. (2010). Structural equation modeling in information systems research using partial least squares. Journal of Information Technology Theory and Application, 11(2), 5-40.

Wu, C., Zollhöfer, M., Nießner, M., Stamminger, M., Izadi, S., \& Theobalt, C. (2014). Real-time shading-based refinement for consumer depth cameras. ACM Transactions on Graphics (ToG), 33(6), 200.

Yuhanis, A. A., \& Chok, N. (2013). The role of halal awareness, halal certification, and marketing components in determining halal purchase intention among non-muslims in Malaysia: a structural equation modeling approach. Journal of International Food \& Agribusiness Marketing, 25(1), 1-23.

Yusoff, F. A. M., Yusof, R. N. R., \& Hussin, S. R. (2015). Halal Food Supply Chain Knowledge and Purchase Intention. International Journal of Economics \& Management, 9, 155-172

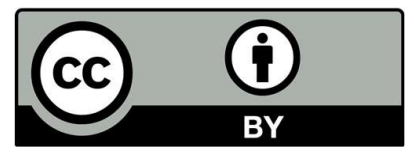

(C) 2019 by the authors; licensee Growing Science, Canada. This is an open access article distributed under the terms and conditions of the Creative Commons Attribution (CCBY) license (http://creativecommons.org/licenses/by/4.0/). 